\title{
Agronomic performance of 27 cocoa progenies and plant selection based on productivity, self-compatibility and disease resistance
}

\author{
Milton Macoto Yamadal, José Luis Pires ${ }^{1}$, Fábio Gelape Faleiro², Uilson Vanderlei Lopes ${ }^{1}$, \\ Mariosvaldo Morais Macedo
}

\begin{abstract}
The objective of the present work was to evaluate 27 progenies of cocoa crosses considering the agronomic traits and select F1 plants within superior crosses. The experiment was installed in March 2005, in the Experimental Station Joaquim Bahiana (ESJOB), in Itajuipe, Bahia. The area of the experiment is of approximately 3 ha, with a total of 3240 plants. Thirteen evaluations of vegetative brooms, five of cushion brooms and 15 of number of pods per plant were accomplished. Thirty pollinations were made for each selected plant to test for self-compatibility. The production, based on the number of pods per plant, and resistance to witches' broom indicated CEPEC 94 x CCN 10, RB 39 × CCN 51 and CCN 10 x VB 1151 as superior progenies. All selections tested were self-compatible. The analyses of progenies and individual tree data, associated to visual field observations, allowed the selection of 17 plants which were included in a network of regional tests to determine the phenotypic stability.
\end{abstract}

Key words: Theobroma cacao, clones, hybrids, genetics and breeding.

\section{RESUMO}

\section{Desempenho agronômico de 27 progênies de cacaueiro e seleção de plantas com base na produtividade, autocompatibilidade e resistência a doenças}

Este trabalho teve o objetivo de avaliar 27 progênies de cruzamentos de cacaueiro, de acordo com as características agronômicas e, dentro destas, selecionar plantas F1 superiores. O experimento foi instalado em Março de 2005, na Estação Joaquim Bahiana (ESJOB), no município de Itajuípe, Bahia. Aárea do experimento é de aproximadamente 3 ha, com total de 3240 plantas. Foram realizadas 13 avaliações de vassoura vegetativa, cinco avaliações de vassoura de almofada e 15 avaliações do número de frutos/planta. Foram feitas 30 polinizações em cada planta selecionada, para testar sua autocompatibilidade. Os dados de produção, baseados no número de frutos por planta e na resistência à vassoura-de-bruxa, indicaram o CEPEC 94 x CCN 10, RB 39 x CCN 51 e CCN 10 x VB 1151 como progênies superiores. Todas as seleções testadas foram autocompatíveis. A análise de dados de progênies e de plantas individuais, associada a observações visuais no campo, permitiu a seleção de 17 plantas, que foram incluídas em uma rede de testes de ensaios regionais, para determinar a estabilidade fenotípica

Palavras-chave: Theobroma cacao, clones, híbridos, genética e melhoramento.

\footnotetext{
Received: 14/06/2012; Accepted: 21/05/2013.

${ }^{1}$ Agronomist engineers. Doctors of Science.. Setor de Genética, Centro de Pesquisas do Cacau (CEPEC)/CEPLAC, Km 22, Rodovia Ilhéus-Itabuna, Caixa Postal 7, 45600-970, Itabuna, Bahia, Brasil. macoto@cepec.gov.br (corresponding author); joseluis@cepec.gov; uilson@cepec.gov.br

${ }^{2}$ Agronomist engineer. Doctor of Science. Embrapa - Centro de Pesquisa Agropecuária dos Cerrados, BR 020, Km 18, Caixa Postal 08223, 73301-970, Planaltina, Distrito Federal, Brasil. ffaleiro@cpac.embrapa.br

${ }^{3}$ Agronomist engineer. Setor de Genética, Centro de Pesquisas do Cacau (CEPEC)/CEPLAC, Km 22, Rodovia Ilhéus-Itabuna, Caixa Postal 7, 45600-970, Itabuna, Bahia, Brasil. mariosvaldo.macedo@ hotmail.com
} 


\section{INTRODUCTION}

The cocoa tree was introduced to the state of Bahia in 1746, with accessions coming from the state of Pará, originating the population named Comum da Bahia. In the 1950's, the first selections and genetic improvement programs were accomplished on this population, to obtain the selections designated as SIC (Seleção Instituto de Cacau), SIAL (Seleção do Instituto Agronômico do Leste) and EEG (Estação Experimental de Guatacazes). In the 1960 's, after the discovery of the heterosis in cocoa, the genetic breeding programs of cocoa turned their focus to several countries for the production of interclonal hybrids. In CEPLAC, with the creation of the Cocoa Research Center (CEPEC) in 1963, started the production of hybrids using the SIC, SIAL and EEG selections as well as clones introduced from Trinidad, Costa Rica, Colombia, Mexico, Peru, Ecuador and the Brazilian Amazonia (Vello et al. 1969).

After the arrival of the disease in 1989, in Bahia, CEPEC started selecting for resistance to witches' broom on farms, mainly in areas of hybrid plantations and in experimental areas. The first clones were recommended to the farmers in 1997. In spite of many selections obtained in the farms, the source of resistance to witches' broom in those selections was restricted, almost exclusively, to Scavina clones (Yamada et al., 2009a).

Currently, the cocoa genetic breeding program at CEPEC tries to associate (pyramiding) genes of different sources of resistance to increase the stability on space and durability of the resistance. In that sense, several progenies have been obtained by the CEPEC's breeding program.

The objective of the present work was to evaluate 27 cocoa progenies for their agronomic traits and select F1 plants within the superior crosses to be used in regional tests of clones and also in advancing generations of breeding.

\section{MATERIALAND METHODS}

The experiment was established in March 2005 at the Experimental Station Joaquim Bahiana (ESJOB), in Itajuipe, Bahia (1441'7' S 39²1'52' W). The experimental area is of approximately 3 ha, with 3240 plants in total, established on a $3 \times 3 \mathrm{~m}$ spacing. Banana trees were used as temporary shade in the midpoint of four cocoa trees, and erythrinas as permanent shade, which were already planted in the area. The plots consisted of 30 seedlings, in a randomized complete block design with four replications. Some parents of the 27 crosses had proven to have good agronomic characteristics in previous trials and germplasm collections and some were already recommended for planting by growers. The mating design used to obtain these progenies was a Single Pair Mating
(SPM) design (Lopes et al., 2011). The crosses evaluated are showed in Table 1.

In this trial, it was evaluated the number of vegetative brooms, the number of cushion brooms, the number of pods per plant, and the self-compatibility status. The evaluations of vegetative brooms were done from August 2005 to June 2010 (13 evaluations) and of cushion brooms from February 2009 to June 2010 ( 5 evaluations). The pod numbers per plant were evaluated from June 2007 to June 2010 (15 evaluations). The compatibility tests were accomplished by making 30 pollinations in each plant, as described by Yamada et al. (1982).

One of the objectives of the trial was also to select resistant plants to Ceratocystis wilt disease, caused by Ceratocystis cacaofunesta, under controlled conditions. However many of the plants died naturally from the disease in the field; probably because the experimental area was previously cultivated with Theobahia, which is very susceptible to the disease, increasing the inoculum density in that area.

The statistical analyses were accomplished aiming to evaluate the productive potential of the progenies and the incidence of vegetative (VV) and cushion brooms (VA). The same data were also used for estimation of genetic dissimilarities among the progenies. The dissimilarity matrix obtained was used for the cluster analysis using the Centroid method. Correlations among the average of pod number per progeny and vegetative broom and cushion broom were also estimated. All analyses were accomplished by using the SAS package version 6.03 (SAS, 1988).

The number of plants used in the analysis varied among crosses, because of death of some plants by Ceratocystis, mainly, and in other cases because the delay

Table 1. List of the 27 crosses evaluated in the experiment installed in the experimental Station Joaquim Bahiana

\begin{tabular}{ll}
\hline Crosses & Crosses \\
\hline T1- PA 285 x TSH 565 & T16- CPEPEC 94 x CCN 10 \\
T2- VB 184 x SGU 54 & T17- TSH 1188 x VB 1151 \\
T3- CEPEC 523 x CCN 51 & T18- EET 62 x VB 514 \\
T4- CEPEC 515 x CC 10 & T19- TSH 565 x CSG 70 \\
T5- CEPEC 94 x AC 01 & T20- EET 45 x CC 10 \\
T6- TSH 565 x VB 184 & T21- CCN 10 x VB 1151 \\
T7- PA 300 x CCN 10 & T22- VB 184 x SIC 19 \\
T8- CASA x CCN 10 & T23- TSH 1188 x SGU 54 \\
T9- TSH 1188 x CC 10 & T24- CC 10 x CCN 10 \\
T10- SGU 26 x CCN 51 & T25- EET 392 x CCN 51 \\
T11- RB 39 x CCN 51 & T26- CEPEC 42 x SIC 19 \\
T12- TSH1188 x CEPEC 515 & T27- CEPEC 515 x SGU 54 \\
T13- PA 169 x CCN 10 & \\
T14- TSH 565 x VB 1139 & \\
T15- TSH 1188 x CCN 10 & \\
\hline T=Treatment from 1 to 27 &
\end{tabular}

T=Treatment from 1 to 27 
in production of plants in some crosses. Based on the statistical analysis and on visual observations in the field, some plants were selected for regional tests.

\section{RESULTS AND DISCUSSION}

The largest average number of pods per tree was observed in the progenies CEPEC 94 x CCN 10, RB $39 x$ CCN 51, CCN 10 x VB 1151 and PA 169 x CCN 10 (Table 2). Also, these four crosses presented the largest number of plants in production (more than 110 plants out of 120); although some other crosses with large number of plants in production presented a low number of pods per plant (Table 2). For this reason, selections were done mainly in these four crosses, as yield production was one of the major characters to be considered in the selection process. However, in relation to vegetative and cushion brooms, those four progenies were not the most resistant, except for RB 39 x CCN 51 (low VV) and CEPEC 94 x CCN 10 ( low VA) and PA $169 \times$ CCN 10, which were in the group of the most susceptible progenies (Table 3). Those four crosses,

Table 2. Analysis of productivity of 27 cocoa progenies, based on cumulative number of pods per tree

\begin{tabular}{|c|c|c|c|}
\hline PROG & $\begin{array}{c}\text { Number total } \\
\text { of trees }\end{array}$ & $\begin{array}{r}\text { Cumu } \\
\text { number } \\
\text { per } \mathbf{t}\end{array}$ & $\begin{array}{l}\text { lative } \\
\text { of pods } \\
\text { tree* }\end{array}$ \\
\hline CEPEC94xCCN10 & 112 & $9.43 \mathrm{a}$ & \\
\hline RB39xCCN51 & 115 & $9.32 \mathrm{a}$ & \\
\hline CCN10xVB1151 & 115 & $8.72 \mathrm{a}$ & \\
\hline PA169xCCN10 & 110 & $8.71 \mathrm{a}$ & \\
\hline TSH1188xCC10 & 71 & $8.13 \mathrm{a}$ & \\
\hline TSH1188xVB1151 & 119 & $7.54 \mathrm{a}$ & abcd \\
\hline EET45xCC10 & 75 & $6.45 \mathrm{a}$ & bcde \\
\hline VB184xSIC19 & 108 & $6.33 \mathrm{a}$ & abcde \\
\hline PA300xCCN10 & 59 & 5.71 & bcdef \\
\hline TSH565xVB1139 & 84 & 5.04 & cdefg \\
\hline TSH565xCSG70 & 55 & 4.33 & defgh \\
\hline VB184xSGU54 & 115 & 3.35 & efghi \\
\hline TSH1188xCEPEC515 & 116 & 3.29 & efghi \\
\hline TSH1188xSGU54 & 111 & 2.96 & efghi \\
\hline CEPEC523xCCN51 & 83 & 2.66 & fghi \\
\hline CEPEC515xCC10 & 84 & 2.34 & fghi \\
\hline TSH565xVB184 & 87 & 2.31 & fghi \\
\hline EET392xCCN51 & 86 & 2.24 & fghi \\
\hline $\mathrm{CC} 10 \mathrm{xCCN} 10$ & 76 & 2.12 & ghi \\
\hline CEPEC515xSGU54 & 100 & 2.11 & hi \\
\hline СЕРЕС94xAC01 & 88 & 1.50 & hi \\
\hline EET62xVB514 & 77 & 1.44 & hi \\
\hline PA285xTSH565 & 86 & 1.23 & hi \\
\hline CASAxCCN10 & 116 & 1.15 & hi \\
\hline TSH1188xCCN10 & 103 & 0.88 & hi \\
\hline CEPEC42xSIC19 & 54 & 0.74 & $\mathrm{i}$ \\
\hline SGU26xCCN51 & 61 & 0.38 & $\mathrm{i}$ \\
\hline
\end{tabular}

* Mean the same letter do not differ statistically followed by for the Tukey test at $1 \%$ of probability. in general, presented also a high susceptibility to Ceratocystis wilt (Ceratocystis cacaofunesta), as observed by the reduced number of plants that survived (Table 3 ).

In the cluster analysis, those four crosses stayed in the same group (cluster 5, Table 4), except RB 39 x CCN 51(cluster 6), because of the smallest number of vegetative and cushion brooms observed (Table 3 ). In the progeny RB 39 x CCN 51, some plants were free of witches' broom or with very low numbers (Table 5, T11) during the evaluation period, reducing the average of this progeny for the resistance traits.

Comparing Tables 2 and 4, the highest number of pods per plant was observed in progenies of the clusters 4,5 and 6 . These results can be explained considering that some parents involved in those progenies (CCN 51, CCN 10, TSH 1188, VB 1151) are high yielding parents (Table 4) recommended for planting by farmers.

Progenies involving CC 10, despite showing high yield (Table 2), were very susceptible to witches` broom (Table 3 ). It has been observed in other trials and germplasm collections that the $\mathrm{CC} 10$ clone possesses a high seed size and is very productive, although susceptible to witches' broom disease.

The progenies in cluster 4 and 5 presented the highest number of cushion brooms (VA, Table 3). On the other hand, with respect to the number of vegetative brooms, progenies of cluster 1 and 2 presented the smallest averages (Table 3); although those progenies were good in relation to pod production (Table 2).

Some progenies, such as TSH 1188 x VB 1151, despite the good pod production, had a large number of vegetative brooms and specially cushion brooms than other crosses (Table 3). For this reason, limited selection was done in this cross. Interestingly, the clones TSH 1188 and VB 1151 are already recommended to farmers, because their high resistance to witches' broom. When the two clones were crossed, they presented a large number of cushion brooms. However, other crosses involving TSH 1188, such as those with SGU 54 and CCN 10, presented a low level of cushion broom infection (Table 3 ).

The Pearson correlation coefficients between the number of pods and the number of vegetative brooms was $\left(0.41^{*}\right)$ and between the number of pods and number of cushion brooms. $\left(0,66^{* *}\right)$. Therefore, in general, the productive progenies are more susceptible to witches' broom.

Considering the pod production, vegetative broom (VV) and cushion broom numbers (VA), the best progenies were RB 39 x CCN 51 (T11) and CCN 10 x VB 1151 (T21). Other progeny of interest was the CEPEC 94 x CCN 10 (Tables 2 and 3). The analyses of progenies and individual data, associated with visual observations in the field, allowed to select 17 plants (Table 5). The selections made 
in each progeny (treatment) were: five in T11, four in T21, two in T23 and for the others 6 selections, one plant per treatment. All 17 selected plants were self-compatible and had good agronomic characteristics, such as number of pods, seed size, shell thickness and resistance to witches' broom. An initial selection of clones can be based on the number of pods and visual observation of the pod size (Efron et al., 2006). Some selections were based only on the visual observation, e.g., ESJOB 07. Others, like ESJOB 34 , in spite of the presence of many vegetative brooms, had a large number of pods (Table 5). Those field observations are also important considering that in the genetic breeding work, the breeders should consider the scientific knowledge with the art (individual ability) as defined by Resende et al. (2011). In the future, observations and data collection will be continued in this trial and other selections will be accomplished. Those outstanding selections have been multiplied and tested in other edaphoclimatic conditions in regional clonal trials in farms of South Bahia, aiming to determine the phenotypic stability of the clones and to confirm their yield and resistance potential. The success in obtaining those selections can be due to the reasonable population size, i.e. around 120 plants per cross (Efron et $a l ., 2006)$ and the high genetic distances and heterozygosity among the parents involved in those crosses as shown in previous studies (Yamada et al., 2009b).

Table 4. Cluster analysis of 27 crosses

\begin{tabular}{lll}
\hline Cluster & \multicolumn{2}{c}{ Crosses } \\
\hline \multirow{2}{*}{ Cluster 1 } & CEPEC515xCC10 & ET392xCCN51 \\
& TSH565xCSG70 & TSH1188xCEPEC 515 \\
& SGU26xCCN51 & \\
\hline & CASAxCCN10 & TSH565xVB1139 \\
Cluster 2 & CEPEC515xSGU54 & TSH1188xCCN10 \\
& PA300xCCN10 & VB184xSGU54 \\
& CEPEC523xCCN51 & TSH565xVB184 \\
\hline Cluster 3 & EET62xVB514 & PA285xTSH565 \\
\hline Cluster 4 & EET45xCC10 & TSH1188xCC10 \\
\hline & CCN10xVB1151 & VB184xSIC19 \\
Cluster 5 & CEPEC94xCCN10 & TSH1188xVB1151 \\
\hline Cluster 6 & PA169xCCN10 & \\
\hline Cluster 7 & CC10xCCN10 & \\
\hline Cluster 8 & CEPEC42xSIC19 \\
\hline
\end{tabular}

Table 3. Statistical analysis of the vegetative broom (VV) and cushion broom (VA) of 27 crosses

\begin{tabular}{|c|c|c|c|c|}
\hline Crosses & $\mathbf{N}$ & Mean (VV) & Crosses & $\operatorname{Mean}($ VA) \\
\hline TSH1188xCC10 & 95 & $10.54 \mathrm{a}$ & TSH1188xVB1151 & $3.08 \mathrm{a}$ \\
\hline EET45xCC10 & 96 & $9.92 \mathrm{a}$ & TSH1188xCC10 & $2.66 \mathrm{ab}$ \\
\hline CC10xCCN10 & 100 & $9.82 \mathrm{a}$ & EET45xCC10 & $2.25 \mathrm{abc}$ \\
\hline VB184xSIC19 & 108 & $9.62 \mathrm{ab}$ & PA169xCCN10 & $1.71 \mathrm{abcd}$ \\
\hline PA169xCCN10 & 110 & $9.24 \mathrm{abc}$ & VB184xSIC19 & 1.53 bcde \\
\hline TSH1188xSGU54 & 111 & $8.31 \mathrm{abcd}$ & RB39xCCN51 & 1.43 bcdef \\
\hline TSH1188xVB1151 & 119 & 7.13 bcde & CCN10xVB1151 & 1.11 cdef \\
\hline CEPEC523xCCN51 & 111 & 7.08 cdef & CEPEC515xSGU54 & 1.10 cdef \\
\hline VB184xSGU54 & 115 & 6.83 cdef & TSH1188xCEPEC515 & 0.99 cdef \\
\hline SGU26xCCN51 & 88 & 6.70 def & CEPEC515xCC10 & $0.80 \mathrm{def}$ \\
\hline PA300xCCN10 & 117 & 6.26 defg & EET392xCCN51 & 0.73 def \\
\hline CEPEC515xSGU54 & 100 & 5.72 efgh & PA300xCCN10 & 0.72 def \\
\hline CCN10xVB1151 & 115 & $5.62 \mathrm{efgh}$ & TSH1188xSGU54 & 0.71 def \\
\hline TSH1188xCEPEC515 & 116 & 5.03 efghi & CEPEC94xCCN10 & $0.68 \mathrm{def}$ \\
\hline CEPEC515xCC10 & 111 & 4.59 fghij & VB184xSGU54 & 0.62 def \\
\hline CEPEC94xCCN10 & 112 & 4.56 fghij & CC10xCCN10 & 0.61 def \\
\hline RB39xCCN51 & 115 & 3.90 ghijk & SGU26xCCN51 & 0.54 def \\
\hline CEPEC42xSIC19 & 110 & 3.84 ghijk & CEPEC 523xCCN51 & 0.49 def \\
\hline TSH565xVB1139 & 114 & 3.74 hijk & CASAxCCN10 & $0.47 \mathrm{def}$ \\
\hline TSH1188xCCN10 & 103 & 3.72 & TSH1188xCCN10 & $0.41 \mathrm{def}$ \\
\hline EET392xCCN51 & 114 & 3.54 & EET62xVB514 & 0.33 ef \\
\hline CASAxCCN10 & 116 & 3.40 & PA285xTSH565 & 0.24 ef \\
\hline TSH565xCSG70 & 114 & 2.96 & TSH565xVB1139 & 0.21 ef \\
\hline TSH565xVB184 & 114 & 2.75 & TSH565xVB184 & 0.18 ef \\
\hline PA285xTSH565 & 113 & 2.46 & CEPEC94xAC01 & 0.17 ef \\
\hline EET62xVB514 & 107 & 2.13 & TSH565xCSG70 & 0.14 \\
\hline CEPEC 94 x AC01 & 117 & 1.69 & CEPEC 42 x SIC 19 & 0.11 \\
\hline
\end{tabular}

* Mean followed by the same letter do not differ statistically for the Tukey test at $1 \%$ of probability.

$\mathrm{N}=$ Total number of trees 
Table 5. The 17 selections with ESJOB code, locations of plants in the experiment, data of vegetative broom (VV), cushion broom (VA), number of pods (NP), compatibility (COMP) and preliminary observations (OBS)

\begin{tabular}{|c|c|c|c|c|c|c|}
\hline ESJOB & Identification & VV & VA & $\mathbf{N P}$ & COMP & OBS \\
\hline$\overline{01}$ & R3-T21-P17 & 4 & 0 & 38 & SC & \\
\hline 02 & R3-T21-P18 & 1 & 1 & 32 & SC & \\
\hline 03 & R1-T23-P1 & 1 & 1 & 31 & SC & \\
\hline 06 & R1-T11-P26 & 0 & 2 & 25 & $\mathrm{SC}$ & $\mathrm{TS}$ \\
\hline 07 & R4-T17-P24 & 9 & 0 & 0 & & \\
\hline 08 & R1-T21-P2 & 2 & 0 & 6 & $\mathrm{SC}$ & BS \\
\hline 10 & R2-T14-P25 & 4 & 0 & 11 & $\mathrm{SC}$ & \\
\hline 11 & R2-T7-P15 & 2 & 4 & 15 & SC & \\
\hline 13 & R3-T21-P16 & 3 & 0 & 24 & & BS \\
\hline 15 & R1-T11-P1 & 0 & 0 & 9 & SC & \\
\hline 21 & R3-T11-P30 & 0 & 0 & 18 & & \\
\hline 32 & R1-T23-P12 & 1 & 0 & 21 & SC & BS,SP \\
\hline 34 & R1-T13-P28 & 24 & 6 & 33 & $\mathrm{SC}$ & \\
\hline 37 & R2-T16-P1 & 2 & 0 & 13 & & \\
\hline 39 & R1-T11-P8 & 1 & 0 & 26 & $\mathrm{SC}$ & \\
\hline 43 & R2-T6-P5 & 8 & 0 & 17 & SC & TS \\
\hline 47 & R1-T11-P20 & 5 & 8 & 13 & $\mathrm{SC}$ & \\
\hline
\end{tabular}

$\mathrm{R}=$ Replications $\mathrm{T}=$ Treatments $\mathrm{P}=$ Number of plant within plots $\mathrm{BS}=$ Big Seeds

$\mathrm{SC}=$ Self-compatible SI $=$ Self-incompatible TS $=$ Thin Shell SP $=$ Small Plants

\section{CONCLUSIONS}

The progenies CEPEC 94 x CCN 10, RB 39 x CCN 51, CCN $10 x$ VB 1151 and PA 169 x CCN 10 were the most productive among those tested in the present trial. The first three also presented a high resistance to witches' broom in the canopy and in the cushions. Selection of individual plants were mainly concentrated in those progenies, resulting in self-compatible selections, with high yield and resistance to witches' broom.

\section{ACKNOWLEDGMENTS}

To the agreement CEPLAC/CNPq for suporting technical project. To Geroncio Nascimento daTrindade and field workers Vivaldo de Souza Ramos and Silvio Ferreira dos Santos who dedicated for the maintenance of the experiment. To Vanessa Paim de Souza and Reinaldo Figueiredo dos Santos for the entrance of data and Lindolfo Pereira Santos Filho for advising on the entrance of the data.

\section{REFERENCES}

Efron Y, Epaina P \& Marfu J (2006) Guidelines for accelerated clone development (ACD) In: Eskes $\mathrm{AB} \&$ Efron Y (Eds.) Global approaches to cocoa germplasm utilization and conservation. Final Report of the CFC/ICCO/IPGRI Project on "Cocoa Germplasm Utilization and Conservation: A Global Approach (1998-2004)" Montpellier, France, p.87-89.

Lopes UV, Monteiro WR, Pires JL, Clement D, Yamada MM \& Gramacho KP (2011) Cacao breeding in Bahia, Brazil - strategies and results. Crop Breeding and Applied Biotechnology, 1:7381.

Rev. Ceres, Viçosa, v. 60, n.4, p. 514-518, jul/ago, 2013
Resende KFM, Santos FMC, Dias MAD \& Ramalho MAP (2011) Implication of the changing concept of genes on plant breeder's work. Crop Breeding and Applied Biotechnology, 11:345-351.

SAS Institute Corporation SAS/STAT (1988) Users'Guide Release 6.03. Cary, NC SAS Inst INC. 1028p.

Vello F, Mariano AH, Garcia JR, Nascimento TF \& Magalhães WS (1969) O programa de melhoramento genético do cacau na Bahia. In: Conferencia Internacional de Pesquisas em Cacau, Salvador. Memórias, CEPLAC. p.43-45.

Yamada MM, Bartley BGD, Castro GCT de \& Melo GRP (1982) Herança do fator compatibilidade em Theobroma cacao L. I. Relações fenotípicas na família PA (Parinari). Revista Theobroma, 12:163-167.

Yamada MM, Gaiotto FA, Flores AB \& Faleiro FG (2009a) Parent pair analysis of cacao trees selected in farms for resistance to Moniliophthora perniciosa using microsatellites. Agrotrópica, 21:123-126.

Yamada MM, Faleiro FG, Flores AB, Lopes UV, Pires JL, Corrêa RX \& Santos RF (2009b) Microsatellite diversity and heterozygosity of parents of cocoa breeding population. Crop Breeding and Applied Biotechnology, 9:17-22. 